\title{
Library and Information Science Research 2002: A Bibliography of Master's Papers from the University of North Carolina School of Information and Library Science
}

The following master's papers were submitted in partial fulfillment of the requirements for the master of science in information and library science degree at the School of Information and Library Science at the University of North Carolina at Chapel Hill. The subject headings used to index them have been given. They are available for interlibrary loan.

Alligood, Tammy. "Privacy Online: A Study of Policy Effectiveness in Electronic Commerce Web Sites." April 2002. 71 pages.

Headings: Electronic commerce; Internet -! Legal aspects; Internet - Security measures; Right of privacy; Surveys - Right of privacy.

Auman, Sarah Abigail. "High School Students' Decisions to Read Print or Electronic Text: Learning Outcomes and Preferences." April 2002. 66 pages. Headings: Books in machine-readable form; Electronic books - Aims and objectives; User interfaces - Evaluation.

Bonnett, Cara. "Mirroring and Managing in Electronic Mentoring: Factors in Interactivity Between Student-Scientist Pairs." April 2002. 66 pages. Headings: Mentoring; Mentoring in education; Computer-mediated communication.

Brown, Ron T. "Studying Database Problems in Small Businesses." April 2002. 45 pages. Headings: Database administrators; Database management systems; Software analysis; Data Quality; University press; Usability.

Bulger, Jennifer Rae. “A Usability Study of Mental Health Websites with an Emphasis on Homepage Design: Performance and Preferences of Those with Anxiety Disorders." January 2002. 74 pages.

Headings: World Wide Web - Homepage; World Wide Web - Usability; Human computer interaction; Mental health - Anxiety disorders.

Cahall, Molynda. "Authentication and Access Issues for Electronic Library Resources at the University of North Carolina-Chapel Hill." July 2002. 41 pages.

Headings: Authentication; College and university libraries; Computers - Access control; Distance education; Internet - Security measures.

Cheemalapati, Sambhavi L. "Information and Development: Strategies for Disseminating Development Literature." April 2002. 64 pages.

Headings: CD-ROMs - Developing countries; Information technology - Africa; Information technology - Developing countries.

Davis, Garad Megan. "Serials Holdings Records in an Online Environment - A Comparison of Fifty Academic Libraries in the United States." April 2002. 48 pages. Headings: Cataloging of serial publications; Electronic journals; Online catalogs. 
Deacle, Jane Register. “Are Alphabet Books Appropriate for Preschool Children to Use to Learn the Alphabet?: A Content Analysis of Age Appropriateness of Ten Alphabet Books Published from 1991-2000." April 2002. 61 pages.

Headings: Alphabet books; Children's reading - Educational aspects; English language - Alphabet - Juvenile literature.

Decker, Ellen Caskie. "The Portrayal of Japanese Americans in Children's Picture Books (1980-1999)." April 2002. 37 pages.

Headings: Children's literature - Evaluation; Content analysis - Children's literature; Japanese Americans; Minorities in literature.

Dockendorf, Dionne M. "Web Page Support for Use of Slang Terms During Internet Searching in Sexual and Reproductive Health." April 2002. 23 pages.

Headings: Contraception - Slang; Internet searching; Reproductive health.

Donaghy, Roger. "Evaluating Online Newspapers Using Established Web Design Guidelines." July 2002. 80 pages.

Headings: Web sites; Web sites - Evaluation; Design - Evaluation; User interfaces - Testing.

Fenton, Serena Jardine. "A Case Study in the Organizational Development of a Digital Library: SunSITE-MetaLab-Ibiblio." April 2002. 121 pages.

Headings: Digital libraries - United States - Planning; Digital libraries - Collection and preservation; Digital libraries - Design; User interfaces (Computer systems) Case studies.

Florence, Brandi L. "'Busting Out All Over': The Portrayal of Superheroines in American Superhero Comics from the 1940s to the 2000s." April 2002. 79 pages. Headings: Comic books, strips, etc.; Comic books, strips, etc. - Women; Comic books, strips, etc. - Evaluation; Women in literature.

Florio, Melissa B. "The Development of a Conversion Model for Programmers Converting a VSAM File to Oracle Tables." April 2002. 75 pages.

Headings: Database - Management - Systems; Databases; Database conversion; Information systems - Design.

Foster, John. "Institutionalizing Success: The Growth of a Digital Strategy in the Cornell University Library System." April 2002. 52 pages.

Headings: Preservation of library materials - Automation; Virtual library; Historical libraries and collections - New York; Optical data processing.

Gotzkowsky, Jolayne S. "Medicine for What Ails You?: A Content Analysis of Information Presented in a Sample of Direct to Consumer Television Advertisements." April 2002. 76 pages.

Headings: Information systems - Special subjects - Drugs; Information systems Special subjects - Consumer education; Content analysis - Television advertising.

Harper, Corey A. "Functional Requirements for Application Profiles: A Step Towards Increased Semantic Interoperability for Metadata." April 2002. 40 pages. Headings: Dublin Core format; Metadata; Conversion; Standards.

Harvey, Aisha A. "Homeless Perspectives of the Public Library." July 2002. 63 pages. Headings: Libraries and communities; Libraries and the homeless; Public libraries - North Carolina.

Hollands, Neil. "Adaptation of Novels into Film - A Comprehensive New Framework for Media Consumers and Those Who Serve Them." April 2002. 75 pages. Headings: Film and television adaptations; Film and television adaptations Evaluation.

Hyde, Kara. "From Suffrage to Postfeminism: An Evolution of the Library of Congress Subject Treatment of Women's Issues." April 2002. 46 pages. 
Headings: Subject headings, Library of Congress; Subject cataloging; Subject headings, Women; Women - United States - History - 20th century; Feminism United States - History - 20th century; Sexism in language.

Imamoto, Rebecca. "Building National Libraries: The British Library and the Bibliotheque Nationale de France." April 2002. 66 pages.

Headings: Library architecture; Library buildings; Architecture and building National libraries; Architecture and building - Program and planning; National libraries - Britain; National libraries - France.

Knowlton, Sean P. "The Future of Latin American Area Studies Librarianship." July 2002. 63 pages.

Headings: Academic libraries; Area studies; Content analysis; Job analysis; Latin America.

Jarvis, Erica C. "Redefining the Feminine in Children's Picture Books." April 2002. 76 pages.

Headings: Sex role - Juvenile literature; Picture books for children - History and criticism; Caldecott Medal - Juvenile literature.

Katte, Jill. "Reaching Out to Researchers: A Model for Web-Based User Education Resources for Archives and Manuscript Collections." April 2002. 46 pages. Headings: Archives - Public relations; Archives - Reference services; Archives Technological innovations; Library orientation; Reference services - Automation.

Johnson, Corey M. "Online Chat Reference: The Awareness of, Use of, Interest In, and Marketing of This New Reference Service Technology." April 2002. 76 pages. Headings: College and university libraries - Reference services; Reference services - North Carolina; Reference services - Automation; Reference services Evaluation; Surveys - Reference services.

LeBlanc, Barbara L. "An Analysis of the Effect of Organizational Placement on the Annual Budget of Special Libraries." April 2002. 43 pages.

Headings: Special libraries; Surveys - Special libraries; Budgets; Placement of librarians.

Long, Holley. "An Assessment of the Current State of Digital Library Evaluation." April 2002. 44 pages.

Headings: Virtual library - Evaluation; Information systems - Evaluation; Research techniques; Use studies - Virtual library.

Lu, Xiaoran. "Web Design and Development for the East Asian Resources of the UNCChapel Hill Academic Affairs Library." May 2002. 41 pages.

Headings: World Wide Web - Design; World Wide Web - Web sites; World Wide Web - Academic libraries; North Carolina libraries - Internet.

McConnell, Kristen. "The Professional Development of Music Librarians." April 2002. 47 pages.

Headings: Music librarians; Music librarians - Education; Continuing education; College and university librarians - Education.

Mikkelsen, Susan K. "Materials Availability and Programming Activities for Hispanic Students: A Survey of North Carolina Elementary School Media Centers." April 2002. 48 pages.

Headings: School libraries - Services to Spanish Americans; School libraries North Carolina; School libraries - Book selection; Multiculturalism; Hispanic.

Mohanty, Suchi. "Physical Comfort in Library Study Environments: Observations in Three Undergraduate Settings." April 2002. 51 pages.

Headings: Architecture and building - Color, decoration, etc.; Architecture and building - Programming and planning; College and university libraries; Furniture. 
Myers, David. "Ticket Tracker: An Electronic Web/Database Ticket System Using Oracle 8 and PHP 4." July 2002. 57 pages.

Headings: Database - Management - Systems; Web databases; Systems analysis; Information storage and retrieval - Design; User interface - Design; User interface - Analysis.

Odess-Harnish, Kerri A. "Making Sense of Leased Popular Literature Collections." April 2002. 45 pages.

Headings: College and university libraries - Acquisitions; College and university libraries - Collection development; Fiction - Acquisitions; Special collections Special subjects - Popular Culture; Surveys - College and university libraries.

Parramore, David. "Ironman Triathlon Digital Library: Design of an Online Training Resource for Triathletes to Plan, Execute, and Advance in Their Training and Racing Goals." July 2002. 76 pages.

Headings: Database - Management - Systems; Databases; Information storage and retrieval - Design; Information systems - Design; Web databases.

Peng, Yutao. "Information Quality of the Jordan Institute for Families Web Site." July 2002. 58 pages.

Headings: World Wide Web; Information quality; Web sites - Evaluation; Survey.

Ruvane, Mary. "Rebuilding a Community with Information: A Community Assessment of Social Capital, Concerns, and Needs." April 2002. 90 pages.

Headings: Community; Community analysis studies; Community development United States; Information needs; Information needs - Analysis; Regional planning - United States - Citizen participation.

Sanborn, Emily C. Jackson. "Other-Field Citation Rates of Library and Information Science Literature." April 2002. 44 pages.

Headings: Citation analysis; Library and information science research.

Signorile, Catherine. "The Perception and Potential of Preservation in Public Libraries." April 2002. 42 pages.

Headings: Preservation of library materials; Public libraries.

Smith, Avena-Lyn. "'A Spell of White Magic': L. M. Montgomery and the Appropriateness of Her Novels for Readers' Advisory Librarians' Use with Adolescent Women." July 2002. 38 pages.

Headings: Public libraries - Readers' advisory services; Young adult literature Lucy Maud Montgomery.

Stambaugh, Emily. "Do Libraries Create Social Capital?" April 2002. 42 pages. Headings: Librarianship - Social aspects; Public relations of libraries - Public libraries; Library programs; Volunteers.

Stachowicz, Christine. "The Effectiveness of Storyboard Surrogates in the Subject Indexing of Digital Video." April 2002. 62 pages.

Headings: Indexing - Video recordings; Information retrieval; Information systems - Special subjects - Video recordings; Internet video; Subject access; Video surrogates.

Sult, Leslie. "A Qualitative Analysis of Internal Marketing Practices at Academic Libraries That Have Undertaken Service Quality Studies." April 2002. 42 pages. Headings: Personnel - Administration; Research libraries - Evaluation; Total Quality Management; Working conditions; College and university libraries -Staff.

Tay, Endrina. "Public Library Paraprofessionals and Their Use of Web Search Tools." April 2002. 61 pages.

Headings: Libraries - North Carolina; Paraprofessionals - Training; Use studies Internet; Internet - Teaching; Internet - Public libraries; Internet search engines. 
Topper, Joby. "Francis Douce and His Collection: An Antiquarian in Great Britain, 1757-1834." April 2002. 77 pages.

Headings: Douce, Francis, 1757-1834; Collectors and collecting - Great Britain; Antiquarians - Great Britain - History - 19th century.

Urquhart, Nicole. "The Effects on Government Documents Reference Service as a Result of a Merger Between the Government Documents Department and Reference Department in an Academic Library." April 2002. 35 pages. Headings: College and university libraries - Reference services; Depository libraries - Reference services; In-service education; Integrated collections; Reference librarians - Education.

Viscount, Carol. "Using the Balanced Scorecard Process for Evaluating the Contribution of a Competitive Intelligence Effort." April 2002. 52 pages.

Headings: Competitive intelligence - Evaluation; Environmental scanning Evaluation; Knowledge management; Information systems - Special subjects Corporations; Business literature - Evaluation; Performance management.

Wang, Yuehong. "AIMS Online Teaching System, An Interactive Web-Based Testing System for Medical School Courses." July 2002. 51 pages.

Headings: Web-based testing; Computer-based testing; Online testing.

Warmouth, Emily K. "The UNC Plant Information Center's 'Ask the Expert' Module: A Usability Study." April 2002. 36 pages.

Headings: Ask the Expert; Usability; Interface; World Wide Web; Plants, Botany.

Warren, Nikki. "Website Log Analysis: Approaches for the Library of the National Institute of Environmental Health Sciences." July 2002. 76 pages.

Headings: Internet - Environmental libraries and collections; Internet - Statistics; Use studies - Internet; Web sites - Case studies; World Wide Web - Statistics.

Webster, Linwood. "The Missing Minority Presence: Minorities, Technology, and Recruitment to Top Ranked American Library Association Information and Library Science Programs." April 2002. 53 pages.

Headings: Black librarians; Information technology; Information industry; Recruiting for librarianship; Library schools - Students; Minority librarians Education.

Westman, Gretchen Daub. "Fixed or Flexibly Scheduled School Library Programs: Teacher Perceptions." April 2002. 63 pages.

Headings: Media programs (Education); School libraries - Evaluation; School libraries - Relations with teachers and curriculum; School libraries - Scheduling.

Whedbee, Lesley. "The Development of Collaboration Skills in Graduate Programs for School Library Media Specialists." April 2002. 36 pages.

Headings: School library media specialists - Professional guidelines; School library media specialists - Graduate education.

Wooten, Kelly. “Women's Zines in the Sarah Dyer Zine Collection." July 2002. 51 pages.

Headings: Dyer, Sarah (Collector); Fanzines; Self-publishing; Young women United States - Social life and customs; Feminism - United States; Underground press publications - United States.

Zhang, Yihua. "Design and Implementation of a Database-Driven Online Survey System for the Organization for Economic Co-operation and Development (OECD) Survey by the National Database on Environmental Management Systems (NDEMS) Project." May 2002. 82 pages.

Headings: Online survey - Design; Database - Management - Systems; Information systems - Design; Interface design; Web databases. 